\title{
Nucleosomal Organization of Telomere-Specific Chromatin in Rat
}

\author{
Vladimir L. Makarov," Serguei Lejnine," \\ Jirair Bedoyan, "† and John P. Langmore" \\ *Biophysics Research Division \\ $\ddagger$ Department of Biological Sciences \\ tGraduate Program in Cellular and Molecular Biology \\ The University of Michigan \\ Ann Arbor, Michigan 48109-2099
}

\section{Summary}

Rat liver interphase chromosomes have telomeres 20$100 \mathrm{~kb}$ in length. Micrococcal nuclease digestion of nuclei cleaves telomeres with a uniform 157 bp periodicity, producing soluble particles that sediment in sucrose gradients exactly like oligonucleosomes. The monomeric telomere particles comigrate with nucleosome core particles on nucleoprotein and DNA gels but do not bind H1. DNAase I cleaves telomere nucleoprotein into a series of bands spaced by about 10.4 bp and with the same intensity distribution as bands from bulk nucleosomes. Removal of H1 from chromatin alters the sedimentation properties of telomeres in parallel with bulk chromatin. Thus, telomeres of mammals are constructed of closely spaced nucleosomes, in contrast with the telomeres of lower eukaryotes, which show no evidence of nucleosomal structure.

\section{Introduction}

Eukaryotic chromosomes are terminated with specialized structures called telomeres, which have many important structural and functional roles in interphase, mitotic, and meiotic chromosomes (e.g., Blackburn and Szostak, 1984; Zakian, 1989; Blackburn, 1991a, 1991 b). Telomeric DNA from most organisms has the consensus sequence $5^{\prime}-\mathrm{C}_{1-8}(\mathrm{~A} / \mathrm{T})_{1-4^{-}} \mathbf{3}^{\prime}$ (Blackburn, 1984). In Oxytricha and Euplotes macronuclei, the chromosomes have very short double-stranded telomeres (20 and $18 \mathrm{bp}$, respectively) with single-stranded G-rich $3^{\prime}$ protrusions (Klobutcher et al., 1981). Tetrahymena and yeast telomeres are about 400-600 bp in length (Blackburn and Gall, 1978; Shampay et al., 1984). Mammalian telomeres consist of the sequence (TTAGGG), terminally repeated for 5-20 kb in humans (Moyzis et al. 1988; Allshire et al., 1988) and 100$150 \mathrm{~kb}$ in mice (Kipling and Cooke, 1990; Starling et al., 1990).

Very little is known about the nucleoprotein structure of telomeres. Telomerase is an enzyme that specifically adds telomeric repeats to the $3^{\prime}$ ends of telomeric DNA, compensating for incomplete replication at the ends of the chromosomes (Blackburn, 1992). Without telomerase activity chromosomes appear to shorten gradually, which might influence cell senescence (Harley et al., 1990). It was shown that, in the ciliates Oxytricha and Euplotes, specialized proteins bind tenaciously to the G-rich single-strand termini and protect against chemical modification and nucleases (Gottschling and Cech, 1984; Gottschling and Zakian, 1986; Price and Cech, 1987; Price, 1990). Tetrahymena and yeast telomeres were also demonstrated to have nonnucleosomal organization (Blackburn and Chiou, 1981; Budarf and Blackburn, 1986; Wright et al., 1992). Several proteins that bind tightly to (TTAGGG) $n$ have been identified or isolated from eukaryotes (Gottschling and Zakian, 1986; Berman et al., 1986; Buchman et al., 1988; Price, 1990; Liu and Tye, 1991; Coren et al., 1991; McKay and Cooke, 1992; Zhong et al., 1992). These findings suggest that telomeres are specialized structures, unlike the nucleosomal substructure characteristic of the bulk of the eukaryotic genome. Specifically, there are no reports that telomeres bind histone proteins or have any repeating subunits.

This paper addresses the question of the nucleoprotein structure in mammalian telomeres. Rat was chosen for study, because the properties of rat chromatin have been investigated in detail (reviewed by van Holde, 1989). Using standard electrophoretic and sedimentation analyses of nuclease-treated telomeres, we unexpectedly found that the bulk of the telomeric DNA is organized into nucleoprotein subunits that are nearly indistinguishable from nucleosomes. The subunits were cleaved with a 10.4 bp periodicity by DNAase I, had a sedimentation coefficient of 11.2S, and were digested with micrococcal nuclease (MNase) to form a stable 146 bp core particle that comigrated with nucleosome core particles on nucleoprotein gels. Each of these properties is characteristic of nucleosome core particles. Oligomers of the telomeric subunits sedimented identically to oligomers of bulk chromatin and were less condensed after treatment of the chromatin with Bio-Rex 70 , which removes histone $\mathrm{H} 1$ from bulk chromatin. The unique features of telomeres in nuclei are an unusually short and regular repeat length of $157 \mathrm{bp}$, a slightly altered MNase sensitivity in nuclei, and an absence of demonstrable binding of histone $\mathrm{H} 1$ to the monomer subunit. We conclude that the telomeres of rat are composed of closely spaced nucleosomes. This result, combined with our finding of very short repeat lengths in telomeres of other organisms (unpublished data), suggests a conserved, unique chromatin structure for telomeres in higher eukaryotes that is probably important for telomere function.

Results

Restriction Enzyme and Bal31 Digestions Show That Rat Telomeres Are Very Long and Are Terminally Located

To confirm that the telomere sequences were primarily at the ends of the chromosomes, intact rat DNA was trimmed with exonuclease Bal31 for increasing times, digested to completion with Haelli, separated by pulse-field electrophoresis, and stained with ethidium bromide before transfer to filters for hybridization with the telomere-specific probe TEL4. Without Bal31 treatment, the telomere fragments were extremely long, consistent with telomere 
A

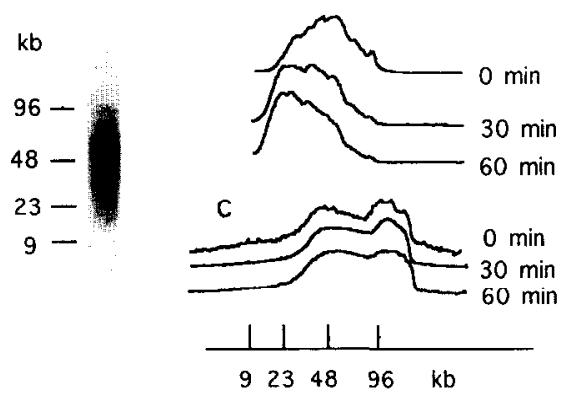

Figure 1. Electrophoretic Analysis of Rat Telomere DNA Size and Location

(A) Agarose-embedded DNA was digested with Haell, electrophoresed by pulse-field inversion in $1 \%$ agarose, electrotransferred to a filter, and hybridized with TEL4. The average size of bulk DNA was $\leqslant 2 \mathrm{~kb}$ (data not shown). To test the specific digestion of the telomeres by Bal31, nuclei in agarose blocks were digested with Bal31 for 0,30 , and $60 \mathrm{~min}$ and subsequently divided into roughly equal parts, digested with Haell or Xhol to achieve an average size of $\sim 50-100$ $\mathrm{kb}$ for telomere and bulk DNA, respectively, and electrophoresed by pulse-field inversion. Bulk and telomere DNA were detected by ethidium bromide staining and TEL4 filter hybridization.

(B) Electrophoretic pattern of telomeres after cleavage with Haelil, showing a gradual decrease in the average size of telomere DNA from $\sim 50 \mathrm{~kb}$ to $\sim 30 \mathrm{~kb}$.

(C) Electrophoretic pattern of bulk DNA after cleavage with Xhol, showing a constant molecular size of $\sim 100 \mathrm{~kb}$. tracts that were 20-100 kb long (Figure 1A). This result was also found with nine other frequently cutting enzymes (Mbol, Mspl, Cfol, Rsal, Hpal, Hinfl, Ddel, Sau3Al, and Alul). Bal31 progressively reduced the size (Figure 1B) and intensity of telomere DNA, in agreement with previous results in human and mouse (Allshire et al., 1988; Starling et al., 1990). Control digestions of the same Bal31digested samples with Xhol showed no change in the length of high molecular weight bulk DNA, indicating that Bal31 was specific to the ends of the chromosomes (Figure $1 C)$. Thus, the TEL4 probe is specific to long tracts of hexameric repeats at the ends of the chromosomes. Cytological studies have also been unable to detect interstitial hexameric repeats in rat (Meyne et al., 1990).

\section{MNase Digestion Reveals That Telomeres Have a Periodic Subunit Structure}

When digested with MNase, bulk DNA exhibited the expected nucleosome ladder with an average repeat of 197 bp (Figure 2A). Surprisingly, the telomere DNA also had a strong band pattern (Figure 2B). Control digestion of the purified rat DNA with MNase produced a broad molecular weight distribution of telomere and bulk DNA. There are three differences between the behavior of telomeres and bulk chromatin. First, each telomere band migrated faster than the corresponding band on the stained gel, indicating
A

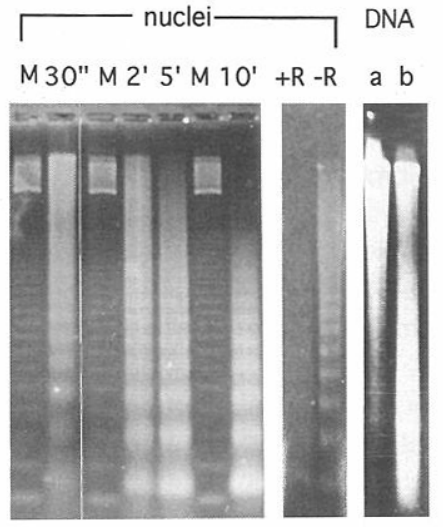

B

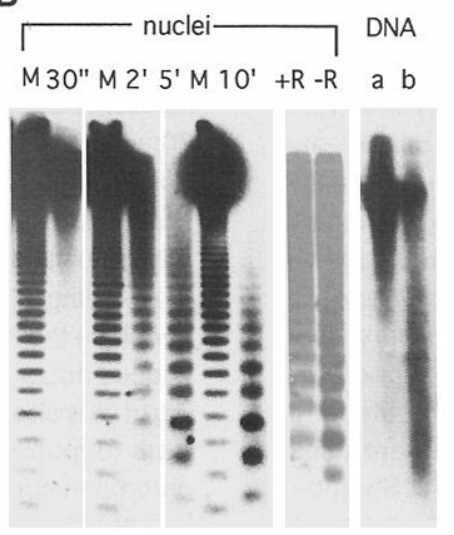

C

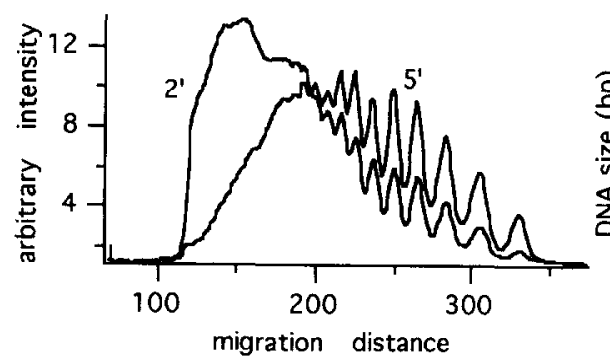

D

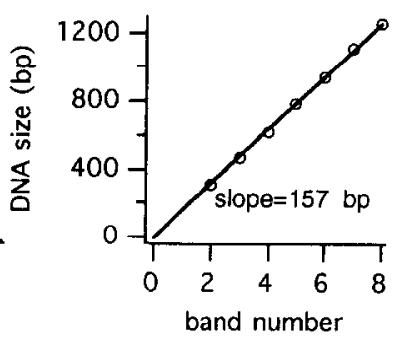

Figure 2. MNase Cleavage Patterns of Rat Liver Nuclei, Assayed by Electrophoresis in $1.5 \%$ Agarose

Nuclei were incubated with $0.04 \mathrm{U}$ of MNase per $\mu \mathrm{g}$ of DNA for the indicated times. Control DNA samples were incubated for $1 \mathrm{~min}$ with $0.002 \mathrm{U}$ of MNase per $\mu \mathrm{g}$ of DNA (lane a); and for $10 \mathrm{~min}$ with $0.01 \mathrm{U}$ of MNase per $\mu \mathrm{g}$ of DNA (lane b). To demonstrate that the telomere ladder was not caused by telomere sequences interspersed with nontelomere sequences, nuclei were digested with $0.04 \mathrm{U}$ of MNase per $\mu \mathrm{g}$ of DNA for $2 \mathrm{~min}$ (lane $-\mathrm{R}$ ), purified, and then digested for $2 \mathrm{hr}$ with $3 \cup$ of Haelll per $\mu \mathrm{g}$ of DNA (lane +R).

(A) Fluorogram of total DNA.

(B) Autoradiogram of telomere DNA and marker DNA hybridized to TEL4 and a probe made from the 123 bp DNA ladder.

(C) Autoradiogram densities from $2 \mathrm{~min}$ and 5 min digests in (B).

(D) Linear regression analysis of the size of telomere DNA fragments after 2 min digestion of nuclei with MNase. The slope indicates a telomere repeat length of $157 \mathrm{bp}$. 
that the repeat length of telomere nucleoprotein was significantly shorter. Second, the telomere bands were sharper and could be visualized at higher molecular weights than bulk chromatin, indicating that the telomere nucleoprotein structure was more regular. Third, the cleavage of the telomeres was slightly slower than that of bulk chromatin. For example, after $10 \mathrm{~min}$ of digestion, the bulk chromatin distribution peaked at the monomer, whereas the telomere DNA distribution peaked at the tetramer and pentamer.

The molecular weights of telomere bands were determined and plotted as a function of band number. Figure $2 \mathrm{C}$ shows the autoradiogram densities for the $2 \mathrm{~min}$ and 5 min time points in Figure 2B. Linear regression analysis shows that all bands fit a straight line (Figure 2D). Analysis of the products of 2,5 , and 10 min digestions gave slopes (and intercepts) of $157(9), 157(-6)$, and $157(-1) \mathrm{bp}$, respectively. We found this short repeat length from six different preparations of rat nuclei. Two preparations were measured carefully and gave repeats of 157 and $158 \mathrm{bp}$. Therefore, we estimate that the true telomere repeat is $157 \pm 2 \mathrm{bp}$. This value is much less than the $197 \mathrm{bp}$ average repeat of bulk rat liver chromatin.

Nucleosomes can move along DNA at high temperatures or salt concentrations, particularly if depleted in histone H1 (Spadafora et al., 1979; Watkins and Smerdon, 1985; van Holde, 1989). As a control for subunit sliding, we digested nuclei with MNase at $0^{\circ} \mathrm{C}, 20^{\circ} \mathrm{C}$, and $37^{\circ} \mathrm{C}$ and determined that the telomere repeat lengths were independent of temperature (data not shown). We conclude that the $157 \mathrm{bp}$ ladder reflects the true average periodicity of telomeres.

\section{MNase Digestion Shows That Most of the Telomere} Nucleoprotein Is Organized as a Repeating Unit That is Neither Unusually Accessible nor Protected Figures $2 \mathrm{~A}$ and $2 \mathrm{~B}$ show that telomeres have a nuclease ladder more definite than that of bulk chromatin, which is consistent with less heterogeneity in the length of the DNA in each repeating unit. The bands still are not as sharp as those of restriction fragments, perhaps owing to some heterogeneity in linker length, cutting at a distribution of sites in the linker DNA, enhanced cleavage of core DNA due to reduced accessibility of the linker DNA, or exonucleolytic trimming. To test directly whether those bands were composed primarily of hexameric repeats of telomere DNA, we redigested the MNase ladder with HaellI (Figures $2 A$ and $2 B$, lanes $-R$ and $+R$ ). Haelll obliterated the bulk nucleosome repeat but had no effect on the telomere repeat, consistent with the 157 bp ladder consisting of pure telomere DNA sequences. Digestion of naked DNA did not reveal a telomere repeat.

To test whether a substantial fraction of the telomere sequences were exceptionally susceptible or protected from MNase, we blotted the digestion samples shown in Figure 2 onto nylon and quantitated the amount of telomere and bulk DNA during the progressive digestion by probing with TEL4 and RAT (the bulk rat DNA probe). The ratio of telomere DNA to bulk DNA remained constant $( \pm 10 \%)$, indicating that telomeres are not rapidly degraded (data not shown). The fact that the 10 min digests in Figure 2B do not have appreciable telomere DNA above $1 \mathrm{~kb}$ shows that there are not long tracts of highly protected telomere DNA. After extensive MNase digestion, more than $75 \%$ of the telomere sequences were present in the monomer, dimer, trimer, and tetramer bands, with the remaining $25 \%$ being in the regions between these bands (data not shown). In comparison, Noll (1974a) used MNase digestion to estimate that at least $85 \%$ of the DNA in rat liver was organized into nucleosomes. These data make it likely that the predominant structure of telomeres is similar to that of bulk chromatin and rule out the possibility that telomeres contain large amounts of free DNA or large refractile complexes.

\section{Telomere Nucleoprotein Is Soluble at Low lonic Strength}

The role of attachment to the nuclear envelope is often attributed to telomeres, owing to evidence of telomere localization at the periphery of the nucleus (e.g., Gruenbaum et al., 1984; Foe and Alberts, 1985; van Dekken et al., 1989; Chung et al., 1990; Rawlins et al., 1991) and interaction of telomere DNA with nuclear matrix (de Lange, 1992). Therefore, telomeres might be insoluble, even under conditions that solubilize most chromatin but leave the nuclear matrix and associated DNA intact.

To study telomere solubility, nuclei were mildly digested and lysed to give $30 \%-50 \%$ solubilization of bulk chromatin (measured by $A_{260}$ ). Dot blots indicated that the telomere fragments were neither enriched nor depleted during solubilization (data not shown). This shows that the telomere fragments are as soluble as bulk chromatin in low salt without divalent cations. Redigestion of the soluble chromatin (or H1-depleted chromatin, shown below) with MNase gave the same repeating subunit patterns as found in nuclei, indicating that the subunits were stable to solubilization (data not shown).

\section{Sucrose Gradient Centrifugation Shows That Telomere Nucleoprotein Sediments as Independent Oligomers with the Same Sedimentation Coefficients as Mononucleosomes and Oligonucleosomes}

Neutral sucrose density gradient sedimentation has been extensively used to separate multimeric nucleoprotein complexes, including chromatin (e.g., Noll and Noll, 1989). The sedimentation of intact chromatin is characterized by a monomer peak with an $S_{20, w}$ of $11.2 S$ and a series of faster bands related to the molecular weight by a power law, which represent oligomers of the nucleosome subunit (Finch et al., 1975; Osipova et al., 1986). We are not aware of any other cellular structures having the same sedimentation coefficients as chromatin fragments.

To compare telomere to bulk nucleoproteins, we analyzed low ionic strength isokinetic sucrose gradients of soluble chromatin (Figure 3). Electrophoresis of the collected fractions showed the expected bands of bulk nucleosome oligomers. Figure $3 A$ shows the ethidium bromide-stained gel of the fractions containing mononucleosomes and some of the dinucleosomes. Figure 3B shows the autoradiogram of the same gel after transfer and hy- 

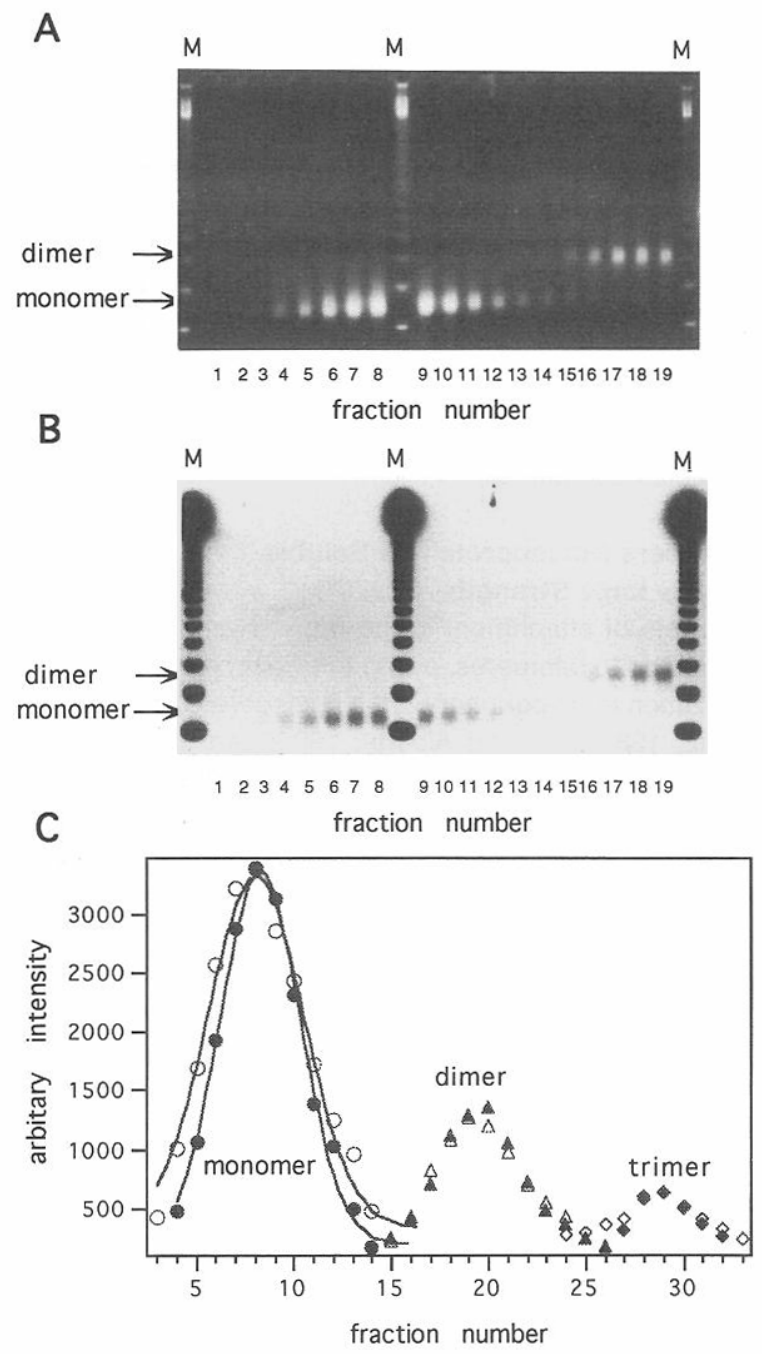

Figure 3. Sedimentation Analysis of Bulk and Telomeric Chromatin Using Isokinetic Sucrose Gradients

Gradient fractions were analyzed by proteolysis, electrophoresis, ethidium bromide staining of total DNA, transfer, and hybridization to TEL4 and $M$ (123 bp marker).

(A) Fluorogram of the first 19 fractions.

(B) Autoradiogram of hybridization to the DNA in (A). The positions of bulk mono- and dinucleosomes are shown.

(C) Graphical analysis. Integrated fluorescence of each fraction (closed circle, triangle, and diamond). Integrated autoradiogram density of each fraction (open circle, triangle, and diamond). The intensity of each telomere band has been multiplied by an arbitrary constant to allow direct comparison of the sedimentation of the bulk and telomere multimers. Lines are Gaussian fits.

bridization to TEL4. The monomer peak on the gradient contained virtually pure monomer-length bulk and telomere DNA, and the same purity was found across the multimer peaks. Quantitation of each of the lanes from fractions containing monomers, dimers, and trimers showed that the profiles of the bulk and telomere bands were indistinguishable (Figure $3 \mathrm{C}$ ). Table 1 compares the sedimentation coefficients of the telomere and bulk bands with previous chromatin studies. We conclude that the hydrodynamic properties of the telomere nucleoprotein frag- ments are virtually identical to those of bulk mono- and oligonucleosomes at low ionic strength.

\section{H1 Depletion Results in Parallel Changes in} Sedimentation of Telomeres and Bulk Chromatin Removal of histone $\mathrm{H} 1$ from chromatin dramatically decreases the sedimentation coefficients of the oligonucleosomes, owing to decondensation of the fibers (Noll and Noll, 1989). To determine whether telomeres underwent the same structural change, we compared sedimentation of intact and $\mathrm{H} 1$-depleted chromatin. Bio-Rex 70 was used to remove histone $\mathrm{H} 1$ selectively from bulk chromatin at low ionic strength without dissociation of other major proteins (Marekov and Beltchev, 1981). SDS-polyacrylamide gel elctrophoresis analysis showed $\leqslant 3 \%$ differential loss of core histones or $\mathrm{HMG} 14 / 17$ and $\geqslant 85 \%$ removal of $\mathrm{H} 1$ (data not shown). Intact and Bio-Rex 70-treated oligonucleosomes from the same preparation of soluble chromatin were centrifuged and analyzed as above (Table 1), giving the same quality of results as shown in Figure 3. Bio-Rex 70 treatment reduced the sedimentation coefficients of both bulk and telomere oligomers, although the telomere fragments sedimented more rapidly than bulk chromatin. We attribute this to the 4-fold shorter linker DNA. These results indicate that telomere multimers are normally condensed but decondense subsequent to treatment with Bio-Rex 70, possibly owing to removal of a nonhistone protein or histone $\mathrm{H} 1$.

\section{Extensive MNase Digestion of Telomeres in Nuclei and H1-Depleted Chromatin Produces Stable Nucleosome Core Particles}

The studies above show that telomeres are organized into repeating subunits that could have the same molecular weight, density, and shape as nucleosomes, but they do not address the issue of internal structure. Extensive MNase digestion and DNAase I digestion produce nucleosome-specific patterns of cleavage within the nucleosome, reflective of the protein-DNA contacts as well as the deformation of the DNA on the surface of the nucleosome (van Holde, 1989).

As MNase progressively cleaves chromatin, there is a brief pause at $166 \mathrm{bp}$, characteristic of the chromatosome, which consists of the histone octamer and one copy of histone $\mathrm{H} 1$ (Simpson, 1978), and a stronger pause at 146 bp, characteristic of the nucleosome core particle, which does not have $\mathrm{H} 1$ (van Holde, 1989). These particles can be unambiguously identified by electrophoresis of the nucleoproteins or DNA. Nucleoprotein electrophoresis has proven very sensitive to the protein composition of mononucleosomes and is able to detect the presence of histone H1, ubiquitinated H2A, and HMG14/17 (Varshavsky et al., 1976; Levinger and Varshavsky, 1982; Barsoum and Varshavsky, 1985). If telomeres are organized as nucleosomes, it is expected that nuclease digestion would produce stable telomere core particles that could be resolved on nucleoprotein and DNA gels.

As the most sensitive test for the presence of nucleosome core particles in telomeres, we digested solublized rat liver chromatin with MNase and performed nucleopro- 
Table 1. Hydrodynamic Properties of Bulk and Telomere-Specific Chromatin

\begin{tabular}{|c|c|c|c|c|c|}
\hline \multirow[b]{2}{*}{ Samples } & \multirow[b]{2}{*}{ Source } & \multicolumn{4}{|c|}{ Sedimentation Coefficients $\left(S_{20, w}\right)$ of Chromatin } \\
\hline & & Monomer & Dimer & Trimer & Tetramer \\
\hline Bulk & Noll and Noll (1989) & $11.2(10.9)$ & $16.0(14.3)$ & $19.7(16.5)$ & $22.7(18.2)$ \\
\hline Bulk & Osipova et al. $(1980)^{a}$ & $10.7(10.6)$ & $15.6(14.1)$ & $19.4(16.7)$ & $22.7(18.8)$ \\
\hline Bulk & Present study & $11.2(10.9)$ & $15.5(14.0)$ & $19.4(16.2)$ & $22.8^{c}(17.8)$ \\
\hline Telomere & Present study ${ }^{\circ}$ & $11.1(10.9)$ & $15.5(14.2)$ & $19.4(17.0)$ & $22.6^{c}(18.7)$ \\
\hline
\end{tabular}

tein gel electrophoresis under the conditions most sensitive to charge, mass, and conformation of the nucleosome core particles (Huang and Garrard, 1989; Pennings et al., 1992). Bulk chromatin showed two clearly resolved monomer bands, previously identified by Varshavsky et al. (1976) as a nucleosome core particle (MN1) and a chromatosome (MN2) (Figure 4A). Transfer of the DNA and filter hybridization to TEL4 showed a single band that comigrated with MN1 (Figure 4B). Excision of the MN1 band and electrophoresis of the naked DNA showed that it contained 146 bp of DNA for both bulk and telomere sequences (Figures 4C and 4D). We conclude that the monomer subunit of telomeres is a stable nucleosome core particle that does not bind histone $\mathrm{H} 1$.

To probe the resistance of telomere core particle DNA to MNase, rat liver nuclei were digested with MNase and analyzed using high resolution DNA gels (Figure 5). Bulk chromatin (Figure 5A, lanes 1 and 2) showed overlapping bands at $166 \mathrm{bp}$ and $146 \mathrm{bp}$, indicative of the presence of the chromatosome digestion intermediate and core particle. In contrast, the telomere fragments showed no evidence of the chromatosome (Figure 5A, lanes 3 and 4), in agreement with the nucleoprotein gels in Figure 4. Better-resolved 166 and 146 bp bands in bulk DNA can be obtained by redigestion of soluble chromatin (data not shown) or nuclei of certain tissues such as chicken erythrocytes (Bavykin et al., 1990), perhaps because more uni- form MNase exonucleolytic trimming is achieved when the linker DNA is more accessible. Figure 5 (lanes 3 and 4) also shows that the telomere core particles are digested to subnucleosomal particles more rapidly than the core particles of bulk chromatin. This result warrants more careful analysis of the MNase digestion of telomeres.

The high resolution MNase digestion patterns of the telomeres are more complex than those of bulk chromatin because of the sequence specificity of the enzyme. Rather than a simple distribution of lengths representing the protection of the DNA from nuclease, the telomere pattern of protein protection was superimposed on a strong 6 bp repeat, owing to the sequence specificity of MNase (e.g., Figure $5 C$, lanes 1-3). Quantitative analysis of the high resolution gels showed that the length of the DNA in the bands, $L$, is described by the expression $L=6 n-3 b p$, where $n$ is an integer. Digestion of naked DNA gave the same $6 \mathrm{bp}$ ladder, owing to the specificity of MNase (Figure $5 C$, lane $D$ ), which is known to cleave A-T 30 times faster than $C-G$ (Drew, 1984). A pause at (C-G) $)_{3}$ during trimming of both telomere strands would account for the band positions.

Telomere DNA consistently failed to show a pause at 166 bp (Figure 5A, lanes 3 and 4), in agreement with the short repeat of $157 \mathrm{bp}$ and the absence of an $\mathrm{H} 1$. containing telomere band on the nucleoprotein gel (Figures $4 A$ and $4 B$ ). Telomere DNA consistently showed a

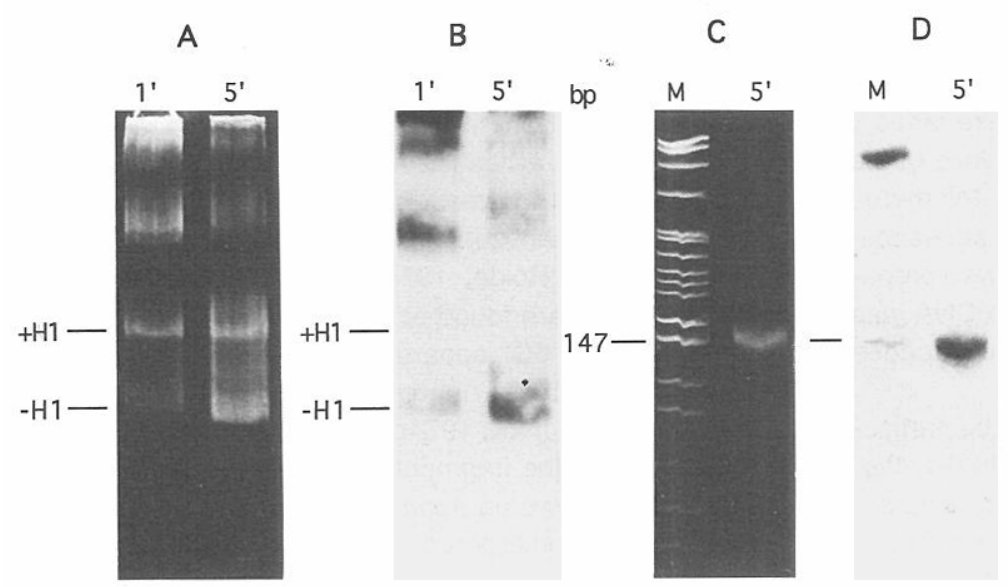

Figure 4. Nucleoprotein Gel Analysis of Material Solubilized from Rat Liver Nuclei after $\mathrm{Di}$ gestion with $0.3 \mathrm{U}$ of MNase per $\mu \mathrm{g}$ of DNA for 1 or $5 \mathrm{~min}$

(A) and (B) show soluble nucleoprotein electrophoresed on $6 \%$ polyacrylamide; (C) and (D) show DNA from the MN1 bands cut from lanes duplicate to the $5 \mathrm{~min}$ digestion in (A) and elec. trophoresed on $8 \%$ agarose to confirm that the putative MN1 bands contained 146 bp of DNA.

(A) Fluorogram of the nucleoprotein gel.

(B) TEL4 hybridization to DNA electrotransferred from the gel in (A).

(C) Fluorogram of DNA cut from the MN1 bands.

(D) TEL4 hybridization to DNA electrotransferred from the gel in (C). The telomere bands comigrated with bulk MN1 bands and contained 146 bp DNA 
A

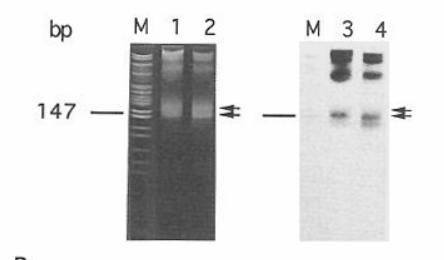

B

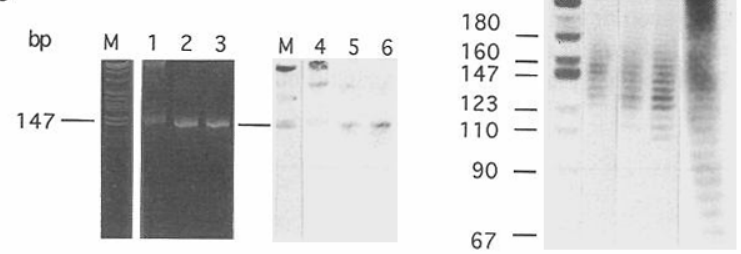

Figure 5. Polyacrylamide Gel Electrophoresis Analysis of Extensive MNase Cleavage of Intact Nuclei and H1-Depleted Chromatin

Samples were digested at $37^{\circ} \mathrm{C}$, the DNA was purified, electrophoresed on polyacrylamide, stained with ethidium bromide, transferred to nylon, and hybridized to TEL4, and a probe was made from the Mspl-digested pBR322 DNA. The Mspl-digested pBR322 DNA was used as a size marker (lane $M$ ).

(A) Digestion of nuclei. Lanes 1 and 2, fluorogram, showing resistance of bulk nucleosomes to digestion below $\sim 146$ bp after digestion of nuclei with $0.4 \mathrm{U}$ of MNase per $\mu \mathrm{g}$ of DNA for 1 and $2 \mathrm{~min}$; lanes 3 and 4, autoradiogram of TEL4 hybridization after electrotransfer of lanes 1 and 2 , showing a pause at $-146 \mathrm{bp}$. Lines show the position of the $147 \mathrm{bp}$ restriction fragment; arrows show the expected positions of DNA fragments with the lengths of chromatosomes (166 bp) and core particles (146 bp). At this level of digestion, the chromatosomes and core particles are clearly present (but not well resolved) in bulk chromatin, but no evidence of the chromatosome is seen in telomeres. (B) Digestion of soluble chromatin depleted of $\mathrm{H} 1$ by washing in 0.5 $\mathrm{M} \mathrm{NaCl}$. Lanes 1, 2, and 3, fluorogram showing resistance of bulk DNA below $\sim 146$ bp after digestion with $0.1 \mathrm{U}$ of MNase per $\mu \mathrm{g}$ of DNA for $0.5,1$, and 2 min; lanes 4,5 , and 6 , autoradiogram of TEL4 filter hybridization of DNA in lanes 1,2, and 3, showing resistance of telomere core particles to digestion below $\sim 146 \mathrm{bp}$.

(C) MNase digestion of a different nuclear preparation, which shows rapid digestion of telomeres to subnucleosomal particles. Lanes 1, 2 , and 3, TEL4 hybridization to nuclei digested with $1 \mathrm{U}$ of MNase per $\mu \mathrm{g}$ of DNA for $0.5,2$, and $10 \mathrm{~min}$. Control DNA was digested with $0.004 \mathrm{U}$ of MNase per $\mu \mathrm{g}$ of DNA for $10 \mathrm{~min}$ (lane D).

pause at about $146 \mathrm{bp}$. The $146 \mathrm{bp}$ peak was usually stronger after redigestion of soluble chromatin or $\mathrm{H} 1$ depleted chromatin (Figure 5B). During digestion the 146 bp core particle is digested further to form subnucleosomal fragments (Figure 5A, lane 4; Figure 5C, lanes 1-3). The telomeres were usually cut into subtelomere particles faster than bulk chromatin (Figure 5A; compare lanes 2 and 4). We speculate that the short-lived presence of the 146 band might be due to association of the telomeres with nuclear matrix or nonhistone proteins or to sequencespecificity of MNase. Figure 5C (lanes 1-3) shows a preparation of rat liver nuclei in which the telomere DNA was quickly cut from $\sim 150 \mathrm{bp}$ to $\sim 120 \mathrm{bp}$, without a pause at $\sim 146 \mathrm{bp}$.

To test whether the telomere subunits might be particularly unstable, rat liver nuclei were treated with $0.1,0.6$, $0.8,1.0$, and $2.0 \mathrm{M} \mathrm{NaCl}$, digested with MNase, and assayed by DNA electrophoresis (data not shown). Treatments with less than $0.8 \mathrm{M} \mathrm{NaCl}$ gave bulk and telomere patterns that were identical to those of untreated nuclei. Above $0.8 \mathrm{M} \mathrm{NaCl}$ the MNase ladders were dramatically and comparably attenuated for both bulk and telomere sequences, presumably owing to removal of histones $\mathrm{H} 2 \mathrm{~A}$ and $\mathrm{H} 2 \mathrm{~B}$ (Burton et al, 1978). These salt experiments were not able to detect a difference in the salt stability of the bulk and telomere nucleosomes.

\section{DNAase I Digestion of Telomeres Demonstrates a Nucleosome-like Protection of One Side of the DNA Molecules}

The internal structure of the telomere subunit was also probed with DNAase I (Figure 6). Rat liver nuclei and DNA were digested with DNAase I, electrophoresed in a denaturing polyacrylamide gel, transferred to nylon, and hybridized to TEL4 and the marker probe, M. Figure 6A shows that bulk chromatin produced a ladder with $\sim 10$ bp spacing extending from $30 \mathrm{bp}$ to $160 \mathrm{bp}$, with strong bands at $\sim 80$ bp and $\sim 90 \mathrm{bp}$ and a weak band at $\sim 60 \mathrm{bp}$, in agreement with previous findings (Noll, 1974b; Prunell et al., 1979). Figure $6 \mathrm{~B}$ and the densitometer tracing of the autoradiogram (Figure 6C) show that telomere nucleoprotein has the same type of repeat pattern, with a very similar distribution of weak and strong bands. A control digestion of purified rat DNA with DNAase I gave a featureless smear for bulk and telomere DNA. Although a 10 bp DNAase I ladder has been observed for DNA bound to inorganic or protein surfaces (e.g., Liu and Wang, 1978; Rhodes and Klug, 1980; Price and Cech, 1987; Price, 1990), strong peaks at $\sim 80$ bp and $\sim 90$ bp and a very weak peak at -60 bp have never been observed for nonnucleosomal DNA. The extents of DNAase I digestion of bulk and telomere chromatin seem to be identical. We conclude that the telomere 10 bp periodicity is specific to a telomere nucleoprotein with the properties of a bulk (i.e., transcriptionally inactive) nucleosome.

Actually, the strong peaks in bulk DNAase I patterns in Figure $6 \mathrm{~A}$ have lengths of $83 \mathrm{bp}$ and $94 \mathrm{bp}$, which has been interpreted as revealing a 10.4 bp repeat of the DNA on the surface of the nucleosome core (e.g., Prunell et al., 1979). A graph of the telomere fragment lengths versus band number (Figure 6D) has a slope of $10.4 \mathrm{bp}$, indicating an average periodicity close to that of bulk chromatin. The strongest telomere bands are centered at 83 bp (Figure $6 \mathrm{C)}$ and $94 \mathrm{bp}$.

There are three additional interesting features of the telomere DNAase I sensitivity seen in the densitometer trace in Figure $6 \mathrm{C}$. First, the $10 \mathrm{bp}$ ladder continues beyond $160 \mathrm{bp}$ to at least $240 \mathrm{bp}$. The same observation has been made for yeast chromatin and interpreted as indicating a quantized spacing between nucleosomes (Lohr and van Holde, 1979). Second, clear telomerespecific bands are found at $\sim 160, \sim 320$, and $\sim 480$ bp (Figures 6B and 6C), apparently representing monomers, dimers, and trimers, noticed previously in bulk rat and yeast chromatin (Noll, 1974b; Lohr and van Holde, 1979). Third, a plot of the fragment length versus band number (Figure 6D) shows an apparently overlapping pattern of telomere bands staggered by $5 \pm 1 \mathrm{bp}$. This pattern has been reported for yeast and chicken chromatin, presum- 


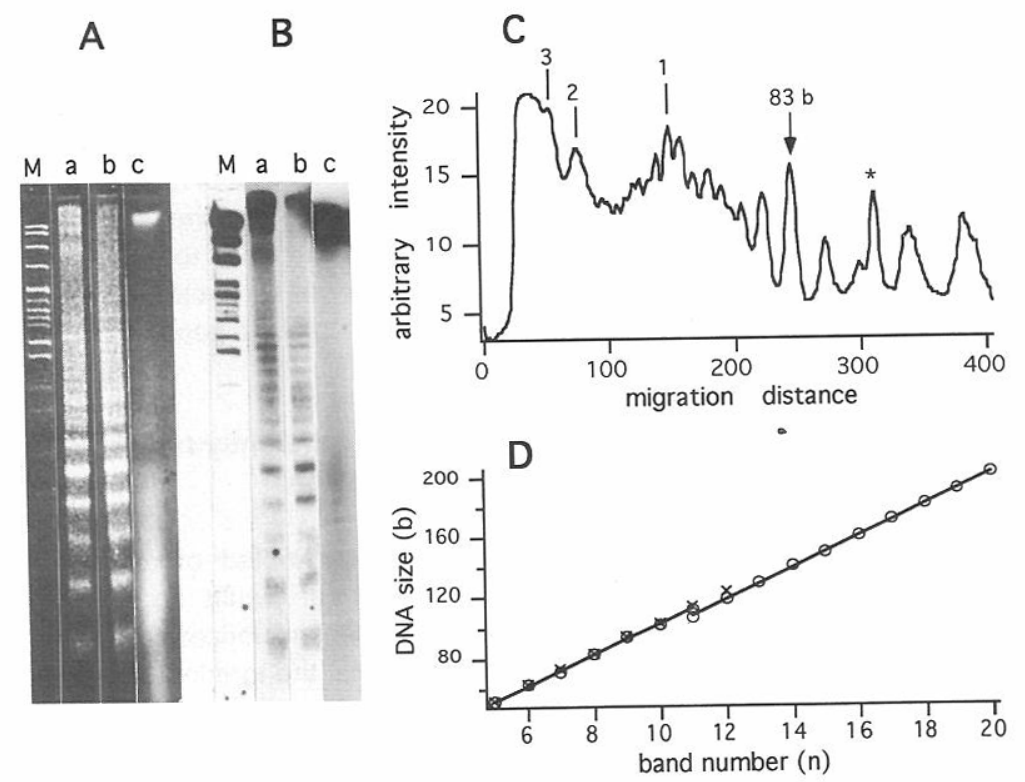

Figure 6. Denaturing Polyacrylamide Gel Electrophoresis Analysis of DNAase I Cleavage of Telomeres and Bulk Chromatin

Rat livers were digested at $37^{\circ} \mathrm{C}$, and the DNA was purified, electrophoresed in $8 \%$ polyacrylamide-7 $\mathrm{M}$ urea, stained with ethidium bromide, transferred to nylon, and hybridized to TEL4 and calibration marker DNA. Lane M, Mspl-digested pBR322 DNA calibration.

(A) Fluorogram.

(B) Autoradiogram.

Lanes $a$ and $b$, nuclei digested for $10 \mathrm{~min}$ with $2 U$ of DNAase I per $\mu g$ of DNA and for 5 min with $10 U$ of DNAase I per $\mu \mathrm{g}$ of DNA; lane c, purified DNA digested for $10 \mathrm{~min}$ with $0.1 \mathrm{U}$ of DNAase I per $\mu \mathrm{g}$ of DNA.

(C) Densitometer tracing of lane a of the autoradiogram. The asterisk represents an artifact, adjacent to band $60 \mathrm{bp}$ (see [B], lane a) on the autoradiogram. Numbers 1,2 , and 3 represent telomere-specific bands 160,320 , and $480 \mathrm{bp}$, respectively.

(D) Graph of band size versus apparent band number, according to the method of Lohr and van Holde (1979). The graphed data (open circles) fit two straight lines: bands 5-11 have a slope of $10.0 \mathrm{bp}$; bands $11-20$ have a slope of $10.4 \mathrm{bp}$. The accuracy of the results is insufficient to suggest that the difference between the two slopes is meaningful. The data of Prunell et al. (1979) (crosses) are also shown.

ably owing to an overlap between the intracore and intercore cleavage patterns, and interpreted as showing that adjacent nucleosomes form on opposite sides of the double helix (Lohr and van Holde, 1979; van Holde, 1989).

The DNAase I data strongly indicate that the telomere subunits have internal structure indistinguishable from that of nucleosomes.

\section{Discussion}

We have studied the nucleoprotein structure of rat telomeres, using classical nuclease, electrophoretic, and hydrodynamic techniques, and found that they are assembled into chromatin with the same repeating core and linker structure as bulk chromatin. By all tested criteria, telomeres are composed of nucleosome core particles. The very short linker is unique to the telomere structure, as is the fact that the monomer does not appear to possess $\mathrm{H} 1$ on nucleoprotein gels. Because the majority of the telomere nucleoprotein properties are identical to those of bulk chromatin, but several are unique, we refer to the telomere nucleoprotein as telomere-specific chromatin. This discussion compares our results with studies of bulk nucleosomes and studies of telomeres from lower eukaryotes.

\section{Rat Chromosomes Have Long Terminal Tracts of Telomere DNA}

We have found that the bulk of the telomere sequences were in continuous $20-100 \mathrm{~kb}$ tracts of the $6 \mathrm{bp}$ repeat, similar to the case in mouse (Kipling and Cooke, 1990; Starling et al., 1990). Assuming an average length of $50 \mathrm{~kb}$, telomere DNA would compose $\sim 0.1 \%$ of the rat genome.
Bal31 digestions showed that these tracts were located at the ends of rat chromosomes, in agreement with in situ hybridization studies (Meyne et al., 1990). Thus, there is nothing extraordinary about the size, sequence purity, or location of rat liver telomere DNA.

\section{Rat Telomeres Are Organized as Regularly Repeating Subunits Having the Same Properties as Chromatin}

MNase has been used to study the repeating nucleosomal substructure of bulk chromatin from many sources, as well as to probe subtle differences between active and inactive genes. There are no known nonnucleosomal structures in prokaryotes or eukaryotes that have the same MNase digestion characteristics as nucleosomes. A MNase digestion ladder is commonly taken as strong evidence that a particular sequence of DNA is organized into nucleosomes.

MNase cleaved the major fraction of rat telomeres at periodic sites that seem to have the characteristics of eukaryotic chromatin. The telomeres were progressively cleaved into lower oligomers of the basic repeat of 157 bp. The length of each oligomer was decreased slightly during extended digestions, as in the case of bulk chromatin during exonucleolytic trimming by MNase. The susceptibility of the telomeres to MNase was slightly less than that of the bulk, which could be the result of the very short repeat length, the constitutive transcriptional inactivity, an interaction with nuclear matrix, or some unknown attribute. The lack of preferential insolubility of the telomere fragments indicates that they are not strongly attached to the nuclear matrix or aggregated into refractile bodies. 
The sedimentation coefficient of chromatin is very sensitive to $\mathrm{H} 1$ content and salt conditions. Thus, it is very significant that the telomere monomers and multimers had the same sedimentation profiles as $\mathrm{H1}$-containing bulk chromatin. $\mathrm{H} 1$ depletion resulted in significant decreases of sedimentation velocities of both bulk and telomere oligonucleosomes, presumably owing to chromatin decondensation (Noll and Kornberg, 1977; Butler and Thomas, 1980). It is likely that $\mathrm{H} 1$ or other proteins affecting condensation are bound to telomeres.

\section{The Telomere Nucleoprotein Subunits Appear to Have the Same Internal Structure as Nucleosomes}

The nucleosome can be defined as a nucleoprotein particle having a core particle, with about $146 \mathrm{bp}$ of DNA and a histone-containing protein core, and a variable amount of DNA linking it to the adjacent core particles. The lengths of the core and linker DNA can be measured directly, as we have done for telomeres in this paper. Although the structure of the globular domain of the histone core has been solved to low resolution by $\mathrm{X}$-ray crystallography (Richmond et al., 1984), the presence of a nucleosome at particular sites in the genome is usually inferred from MNase and DNAase I studies, as described above. In fact, nucleosomes consist of a class of structures, some of them distinguishable by the indirect methods but as yet not characterized by crystallography or microscopy. For example, the class of subunits called nucleosomes includes particles having the following: different DNA sequences; different thermodynamic stabilities; different amounts of linker DNA, from 0 to $100 \mathrm{bp}$; different overall levels of nuclease sensitivity; different solubilities; different levels of histone posttranslational modifications, such as ubiquitination, acetylation, phosphorylation, and poly ADP-ribosylation; different stoichiometries of histone subtypes; different core histone and $\mathrm{H} 1$ stoichiometries; and different nonhistone protein components, including HMG14/17 and satellite-specific proteins (van Holde, 1989 and references therein). The nuclease sensitivities and physical properties of most of those nucleosome subtypes have not yet been studied in detail; however, many of the subtypes are known or suspected to have altered thermodynamic stabilities, sedimentation coefficients, and mobilities on nucleoprotein gels.

Nucleoprotein gel electrophoresis showed that the telomere monomer comigrated with the nucleosome core particle and had a DNA length of about $146 \mathrm{bp}$. This is a very good indication that the telomere subunit has the same protein composition as a nucleosome core particle, because small changes in protein composition (e.g., binding of $\mathrm{HMG} 14 / 17$, monoubiquitination of $\mathrm{H} 2 \mathrm{~A}$, or binding of $\mathrm{H} 1)$ or in DNA length are known to affect the migration of nucleosomes significantly.

In addition, DNAase I digested telomeres and bulk chromatin at the same rates and gave the 10.4 bp periodicity and specific pattern of strong and weak bands that is a unique signature of protection of the core DNA by the histone octamer core.

Although the MNase and DNAase I data are strong enough to conclude that telomeres are composed of nucleosomes, they do not prove that the telomere core particle has exactly the same structure as the core particle studied by X-ray crystallography, nor that the telomere subunits are organized into the same type of higher order structure as bulk chromatin. Nevertheless, the properties of the rat telomere nucleosomes are close to the center of the spectrum of properties known for nucleosomes at other transcriptionally inactive sites of the genome and in other organisms.

\section{Rat Telomeres Are Organized Differently from Telomere and Subtelomere Regions of Lower Eukaryotes}

Rat telomeres are primarily constructed of repeating nucleosomal subunits, although our results do not preclude a small fraction of the telomere nucleoprotein having alternative structure. For example, the terminal 100-500 bp of the chromosomes could have structure similar to the telomeres of lower eukaryotes, but they only represent $<1 \%$ of the rat telomere DNA. The MNase digestions were unable to detect any highly susceptible telomere material (such as free DNA) or highly refractile telomere material. More than $75 \%$ of the soluble telomere nucleoprotein was organized as nucleosomes.

Nucleosomal organization of telomeres has not been reported for any of the other organisms studied previously, which have been limited to lower eukaryotes. In Saccharomyces cerevisiae, a nonnucleosomal nucleoprotein structure has been reported for the terminal tracts of $\mathrm{C}_{1-3} \mathrm{~A}$ repeats (Wright et al., 1992). The yeast telomere nucleoprotein complex, called the telosome, seems to protect the entire $\sim 350$ bp terminal tract and contains a number of proteins, including the regulatory protein RAP1, which does not bind to (TTAGGG) (e.g., Berman et al., 1986; Buchman et al., 1988; Conrad et al., 1990; Liu and Tye, 1991; Wright et al., 1992). Other lower eukaryotes also show no evidence of a nucleosomal structure on the telomere repeat (e.g., Gottschling and Cech, 1984; Budarf and Blackburn, 1986; Price and Cech, 1987; Price, 1990; Edwards and Firtel, 1984). This difference between the major telomere nucleoproteins of higher and lower eukaryotes might be correlated with differences in the availability of nonhistone proteins that are able to bind telomere DNA or differences in the physical structure of the telomere DNA or might simply be due to differences in length of the terminal tracts, which are 10-100 times larger in higher eukaryotes.

In contrast, the subtelomere regions of lower eukaryotes such as S. cerevisiae, Oxytricha, Tetrahymena, and Dictyostelium discoideum can form nucleosomes (Gottschling and Cech, 1984; Wright et al., 1992; Budarf and Blackburn, 1986; Edwards and Firtel, 1984). However, these subtelomere nucleosomes are unlike the telomere nucleosomes of rat, because those subtelomere nucleosomes are not regularly spaced and have the same average repeat length as bulk chromatin (e.g., 160 bp in yeast and 200 bp in Oxytricha).

Thus, telomere-specific chromatin seems to be specific to higher eukaryotes. 


\section{Telomere Chromatin Has an Unusually Short Repeat Length}

The repeat length of $157 \pm 2$ bp was determined at early stages of digestion process, using linear regression analysis, and was reproducibly measured with six different nuclear preparations. Very similar results were obtained after extensive digestions of nuclei, soluble chromatin, and $\mathrm{H} 1$ depleted chromatin. This is the smallest repeat ever measured for a higher eukaryote and the largest ( $40 \mathrm{bp}$ ) deviation from an average repeat reported for any eukaryote. It has been hypothesized that the nucleosome repeat of higher eukaryotes is always greater than $165 \mathrm{bp}$, because the basic subunit might be the chromatosome, consisting of the nucleosome core plus an additional 20 bp of DNA and one molecule of $\mathrm{H} 1$. Because the telomere repeat is less than $165 \mathrm{bp}$, rat telomeres cannot be constructed of chromatosomes, consistent with our nucleoprotein gel results.

We do not understand the origin of unusually short repeat length of rat telomere chromatin. Our controls have ruled out the possibility that the short repeat is due to sliding of nucleosomes during enzymatic digestion. MNase digestions of other tissues and organisms show that the short repeat is probably conserved in all vertebrates and even some invertebrates (unpublished data). Therefore,

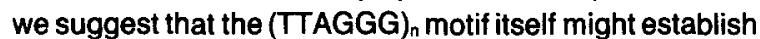
the short repeat. Natural sequence-specific nucleosome spacing for arrays of nucleosomes has not been reported, except in the case of rat satellite chromatin, which has a 185 bp repeat on a 370 bp sequence repeat (Omori et al., 1980 ). In the case of telomeres, it is not obvious how the 6 bp sequence repeat might be related to the $157 \mathrm{bp}$ nucleosome repeat. Perhaps this average repeat is due to a distribution of nucleosome phases at different multiples of the hexameric repeat, e.g., 156 and 162 bp. Alternatively, the short repeat might be due to strong influences from subtelomere chromatin or nonhistone proteins during assembly or in association with nuclear matrix. For example, strongly cooperative polymerization of nonhistone proteins at the very ends of chromosomes might cause in vivo sliding of nucleosomes into compressed arrays in the proximal end of the telomere and perhaps subtelomere regions.

The only other chromatin molecules with very short repeats are found in certain lower eukaryotes, mammalian neurons, and active genes. In fungi the repeats are -170 bp in Neurospora crassa, 165 bp in S. cerevisiae, 158 bp in Achlya ambisexualis and 154 bp in Aspergillus nidulans (van Holde, 1989 and references therein). Several of the fungi seem to have complete complements of all five histones, although they often display significant molecular weight and amino acid composition differences from the more highly conserved histones of higher eukaryotes. However, in many cases nucleosome sliding has not been ruled out. A recent careful study of Schizosaccharomyces pombe showed that the repeat length was about $156 \mathrm{bp}$ but was reduced dramatically, owing to sliding, during digestion and resulted in an abnormally large monomer of 160-180 bp (Godde and Widom, 1992). In contrast, the telomere-specific repeat of rat was not sensitive to the extent or temperature of digestion and gave a monomer DNA size less than the repeat length. Each of these properties is consistent with trimming of the telomere fragments rather than sliding of the nucleosomes. The shortest repeat found previously in mammals was $\sim 160-165 \mathrm{bp}$, in nuclei isolated from neurons in rabbit and rat (van Holde, 1989). It has been proposed that short nucleosome repeats are correlated with transcriptional activity (e.g., Villeponteau et al., 1992), but there is no evidence of telomere transcription in higher eukaryotes.

\section{Telomere-Specific Nucleosomes Are Unusually Uniformly Spaced}

In rat liver, the MNase ladders of telomeres seem to be more distinct than those of bulk or even satellite chromatin (see Omori et al., 1980). About 14 telomere bands can be detected, indicating a very regular repeat. The DNAase I ladder of telomeres extends beyond $240 \mathrm{bp}$, indicating that a substantial portion of nucleosomes have a quantized spacing. Both yeast bulk chromatin and rat telomere chromatin have overlapping patterns staggered by $5 \mathrm{bp}$, implying that the linker is quantized to lengths of $(10 n+5)$ bp and that adjacent nucleosomes are on opposite sides of the DNA helix. The apparent regularity of the telomere repeat might be the result of one of the following: the short repeat length, which would restrict the number of possible positions of the cores and might interfere with the binding of nonhistone proteins; phased positioning of the cores on the (TTAGGG) $)_{n}$ repeat; increased interactions between adjacent nucleosome cores; or specific interactions between the telomeres and soluble nonhistone proteins or nuclear matrix

\section{The Telomere Mononucleosome Often Appears to Be Less Stable to MNase Digestion Than Bulk Nucleosomes}

Telomere sequences in rat nuclei, soluble chromatin, and $\mathrm{H} 1$-depleted chromatin can be digested into core particles having about 146 bp of DNA, which has been regarded as characteristic of all cellular, viral, and synthetic nucleosomes, even for the short repeat length chromatins of fungi, neurons, and active genes. In most nuclear preparations, however, the discrete telomere band at 146 bp was more quickly degraded into subnucleosomal fragments than were bulk nucleosomes. This unusual feature is perhaps due to a difference in packing of telomere nucleosomes in nuclei, interactions of telomeres with nuclear matrix, or perhaps a special combination of MNase sequence specificity and placement of the nucleosomes on the hexameric repeat. Another possibility is that histone $\mathrm{H} 1$ or nonhistone binding to the very short linker DNA alters the stability or accessibility of the ends of the core DNA. Unfortunately, few sequence-specific nucleosome cores have been studied carefully, and no studies have been done to quantitate the relative stabilities of different core particles to MNase. Most studies of nucleosomes are limited to analysis of low resolution gels, which cannot resolve the observed instability of the telomere subunits in nuclei. Therefore, we do not know whether telomere 
cores exhibit special instability or merely fall in the range of stabilities that would be found at other sites in the genome.

\section{The Existence of Soluble Telomere-Specific Chromatin Has Implications for the Study of Telomeres}

We conclude that the telomeres of rat consist largely of a regular array of very closely spaced nucleosomes. This unique chromatin structure is possibly important for telomere function.

It was unexpected that telomeres were as soluble as bulk chromatin, because cytological and biochemical data indicated that telomeres of higher eukaryotes are closely associated with the periphery of the nucleus or nuclear matrix (e.g., Gruenbaum et al., 1984; Foe and Alberts, 1985; van Dekken et al., 1989; Chung et al., 1990; Rawlins et al., 1991). For example, in HeLa cells, telomere DNA cannot be solubilized from nuclei treated to remove histones and digested with restriction enzymes (de Lange, 1992). We conclude that either the attachments to matrix are sensitive to low salt and EDTA or the attachments are few in number. Possibly the telomere termini, which might have single-stranded G-rich protrusions tenaciously bound to specialized proteins (as found in ciliates), could play a role in attachment. Alternatively, the subtelomere regions could be attached to matrix.

Telomere-specific chromatin might influence the attachments of the ends of the chromosomes to nuclei, the resistance of telomeres to degradation, the expression of adjacent genes, regulation of the length of telomeres, the timing of telomere replication, the binding and activity of telomerase, or the roles of telomeres in recombination. It is not known whether the short, regular repeat length of the telomeres influences any of these possible roles for telomeres. We can speculate, however, that the unique, regular nucleosome repeat could increase the cooperativity of packing of the nucleosomes, perhaps influencing the accessibility of telomeres to nonhistone proteins, or could contribute to interactions between telomeres on different chromosomes, perhaps influencing homologous pairing and recombination. Hypothetically, a highly cooperative interaction of the telomere nucleosomes could propagate into the subtelomere regions and influence the expression of adjacent genes (Wright and Shay, 1992), although nucleosome-mediated effects do not seem to play a part in yeast telomere positional effects (Gottschling et al., 1990).

\section{Experimental Procedures}

\section{Materials}

Leupeptin (as hemisulfate) and N-lauroylsarcosine (Sarkosyl) were obtained from Sigma. MNase, DNAase I, RNAase A, and proteinase $\mathrm{K}$ were obtained from Boehringer Mannheim. Random prime DNA labeling kit, Bal31, T4 kinase, 123 bp DNA ladder, Hindlll-digested $\lambda$ DNA, $\lambda$ DNA, and restriction endonucleases Alul, Ddel, Haelil, Hpall, Mbol, and Sau3Al were obtained from Bethesda Research Laboratories. Restriction endonucleases Cfol, Hinfl, Mspl, and Rsal were obtained from Promega. Msp-digested pBR322 DNA and $\lambda$ pulse-field gel marker DNA were obtained from New England Biolabs. Zeta-probe nylon membranes were obtained from Bio-Rad. $\gamma$-[32P]ATP $(3000-6000$ $\mathrm{Ci} / \mathrm{mmol})$ and $\gamma-\left[{ }^{32} \mathrm{P}\right] \mathrm{dCTP}(3000 \mathrm{Ci} / \mathrm{mmol})$ were obtained from Amersham. Oligonucleotide TEL4, (TTAGGG) $)_{4}$, was synthesized on an Applied Biosystems Model 391 DNA synthesizer. Rats (Rattus nor- vegicus, Sprague Dawley, CD) were obtained from Charles River Laboratories.

Preparation of Nuclel, Soluble Chromatin, and Purifled DNA Nuclei from 3. to 9-month-old male and female outbred rats were prepared by a modified Hewish and Burgoyne method as described by Kornberg et al. (1989), except all buffers contained 1 mM EDTA, 0.5 mM EGTA and included protease inhibitors $1 \mathrm{mM}$ phenylmethylsulfonyl fluoride (PMSF) and $6 \mu \mathrm{M}$ leupeptin. lodoacetate was also present during homogenization $(5 \mathrm{mM}$ ) and first centrifugation (1 $\mathrm{mM}$ ). All procedures in this manuscript were carried out at $4^{\circ} \mathrm{C}$, except as noted. Nuclei were suspended in buffer A (15 mM Tris- $\mathrm{HCl}[\mathrm{pH} 7.5] 60 \mathrm{mM}$ $\mathrm{KCl}, 15 \mathrm{mM} \mathrm{NaCl}, 0.15 \mathrm{mM}$ 2-mercaptoethanol, $0.15 \mathrm{mM}$ spermine, $0.5 \mathrm{mM}$ spermidine, $1 \mathrm{mM}$ EDTA, $0.5 \mathrm{mM}$ EGTA, $0.34 \mathrm{M}$ sucrose) supplemented with $50 \%$ glycerol, frozen in liquid nitrogen as $0.1 \mathrm{mg}$ aliquots, and stored at $-70^{\circ} \mathrm{C}$ for $1-2$ months. Concentrations are always stated in terms of DNA concentration, estimated by $A_{200}$, assuming that one absorbance unit is equivalent to $50 \mu \mathrm{g} / \mathrm{ml}$. Before use, each aliquot of nuclei was thawed on ice and washed 2 times with 1 $\mathrm{ml}$ of buffer $\mathrm{C}$ (buffer $\mathrm{A}$ without EDTA and EGTA) by centrifugation for $15 \mathrm{~min}$ at $180 \times \mathrm{g}$.

To produce immobilized nuclei and DNA, nuclei were washed and resuspended to $2 \mathrm{mg} / \mathrm{ml}$ in buffer $A$, mixed gently with an equal volume of $2 \%$ low melting agarose at $37^{\circ} \mathrm{C}$, solidified as $10 \times 5 \times 2 \mathrm{~mm}$ plugs, and divided into $\sim 2 \mu \mathrm{g}$ pieces. To produce salt-treated nuclei, the pieces were washed in $1 \mathrm{ml}$ of buffer $C$ with $0.1-2.0 \mathrm{M} \mathrm{NaCl}$ for $3 \mathrm{hr}$, with hourly buffer replacement to remove soluble protein, and subsequently washed 3 times for 20 min with $1 \mathrm{ml}$ of buffer $\mathrm{C}$.

Chromatin was solubilized by mild MNase digestion of nuclei and low ionic strength lysis (Kornberg et al., 1989). Briefly, $-350 \mu \mathrm{g}$ of nuclei were suspended in $200 \mu$ l of MNase digestion buffer (buffer $C$ with $1 \mathrm{mM} \mathrm{CaCl}$ ), incubated for $5 \mathrm{~min}$ at $37^{\circ} \mathrm{C}$, and digested with 0.23 $\mathrm{U} / \mu \mathrm{g}$ for different times at $37^{\circ} \mathrm{C}$. Digestion was stopped with $10 \mathrm{mM}$ EDTA, and the nuclei were gently sedimented and resuspended for $1 \mathrm{hr}$ at $4^{\circ} \mathrm{C}$ either in $1 \mathrm{mM}$ EDTA, $8 \mathrm{mM} \mathrm{Na}_{2} \mathrm{HPO}_{4}(\mathrm{pH} \mathrm{7.0)}$, and 0.1 $\mathrm{mM}$ PMSF or in $1 \mathrm{mM}$ Tris-HCl $(\mathrm{pH} 8.0)$ and $0.2 \mathrm{mM}$ EDTA. Soluble chromatin was recovered by microcentrifugation for $5 \mathrm{~min}$.

High molecular weight DNA in agarose was prepared by incubating $100 \mu \mathrm{l}$ of immobilized nuclei with $0.5 \mathrm{ml}$ of solution of $200 \mu \mathrm{g} / \mathrm{ml}$ proteinase $\mathrm{K}, 0.5 \%$ SDS, and $100 \mathrm{mM}$ EDTA $(\mathrm{pH} 8.0)$ for $12 \mathrm{hr}$ at $50^{\circ} \mathrm{C}$ followed by washing with $-10 \mathrm{ml}$ of TE $(10 \mathrm{mM}$ Tris- $\mathrm{HCl}$ [pH 8.0], $1 \mathrm{mM}$ EDTA). Soluble DNA was prepared by standard phenol-chloroform extraction, ethanol precipitation, washing with $70 \%$ ethanol, and resuspension in TE at $1 \mathrm{mg} / \mathrm{ml}$. It was incubated with $50 \mu \mathrm{g} / \mathrm{ml}$ RNAase (DNAase-free) for $1 \mathrm{hr}$ at $37^{\circ} \mathrm{C}$ and purified again, as described above.

\section{MNase and DNAase I Digestion}

Washed nuclei were suspended at a concentration of $1 \mathrm{mg} / \mathrm{ml}$ in MNase digestion buffer or DNAase I buffer (buffer $C$ with $3 \mathrm{mM} \mathrm{MgCl}$, $0.1 \mathrm{mM} \mathrm{CaCl}_{2}$ ). Aliquots $(100 \mu \mathrm{l})$ were heated at $37^{\circ} \mathrm{C}$ for $1 \mathrm{~min}$, added to nuclease, and incubated at $37^{\circ} \mathrm{C}$, unless stated otherwise (time and enzyme concentrations in figure legends). Digestion was stopped by adding EDTA to $20 \mathrm{mM}$, SDS to $0.5 \%$, and proteinase $\mathrm{K}$ to 200 $\mu \mathrm{g} / \mathrm{ml}$, followed by incubation at $37^{\circ} \mathrm{C}$ or $50^{\circ} \mathrm{C}$ for $12 \mathrm{hr}$. DNA was extracted twice with phenol-chloroform, ethanol precipitated, washed with $70 \%$ ethanol, and dissolved in TE (after MNase) or deionized formamide with $1 \mathrm{mM}$ EDTA (after DNAase l). After DNAase I digestion, the samples were incubated with RNAase and repurified.

Agarose-embed ded and salt-treated nuclei ( $2 \mu \mathrm{g}$ of DNA) were preincubated in $50 \mu \mathrm{l}$ of MNase buffer for $30 \mathrm{~min}$ and then with $0.4 \mathrm{U}$ of MNase for $15 \mathrm{~min}$ to let the enzyme diffuse into the gel. Digestion was started by heating to $37^{\circ} \mathrm{C}$ and stopped by chilling to $4^{\circ} \mathrm{C}$, and the products were incubated overnight with $10 \mu$ of $20 \mathrm{mM}$ EDTA, $0.5 \%$ Sarkosyl, and $200 \mu \mathrm{g} / \mathrm{ml}$ proteinase $\mathrm{K}$ at $50^{\circ} \mathrm{C}$, removed from the gel at $68^{\circ} \mathrm{C}$, and extracted with phenol-chloroform.

Purified DNA $(200 \mu \mathrm{g} / \mathrm{ml})$ was digested as above with $0.002-0.01$ $U$ of MNase or $0.1 \mathrm{U}$ of DNAase I per of $\mu \mathrm{g}$ DNA, treated with SDS and proteinase $\mathrm{K}$, and extracted with phenol-chloroform.

\section{DNA Restriction and Bal31 Digestion}

Pieces $(2 \mu \mathrm{g})$ of immobilized DNA were washed twice for $\mathbf{3 0} \mathrm{min}$ in TE with $1 \mathrm{mM}$ PMSF, washed 3 times in TE, incubated for $30 \mathrm{~min}$ in $100 \mu \mathrm{l}$ of appropriate restriction buffer at room temperature, and then 
restricted. Digestion with $5 \mathrm{U}$ of enzymes per $\mu \mathrm{g}$ of DNA was done in $100 \mu \mathrm{l}$ of recommended buffer for $16 \mathrm{hr}$ at $37^{\circ} \mathrm{C}$. Bal31 digestion of immobilized intact DNA was performed in $100 \mu$ l of buffer, containing $20 \mathrm{mM}$ Tris- $\mathrm{HCl}$ (pH 7.5), $600 \mathrm{mM} \mathrm{NaCl}, 12 \mathrm{mM} \mathrm{MgCl}, 12 \mathrm{mM} \mathrm{CaCl}_{2}$, and $3 \mathrm{U}$ of Bal31. Samples were incubated with enzyme at $4^{\circ} \mathrm{C}$ for $30 \mathrm{~min}$ and then at $37^{\circ} \mathrm{C}$ for 30,90 , and $120 \mathrm{~min}$. Reactions were stopped by $100 \mathrm{mM}$ EDTA, $0.5 \%$ SDS, and $200 \mu \mathrm{g}$ of proteinase $\mathrm{K}$, and the DNA was digested overnight at $37^{\circ} \mathrm{C}$, washed as above, digested with $5 \mathrm{U}$ of Haell per $\mu \mathrm{g}$ of DNA, and deproteinized as above. Samples were stored in TE buffer before electrophoresis.

\section{DNA Electrophoresis, Southern Blot, and Dot Blot Analyses} Agarose, polyacrylamide, and denaturing polyacrylamide-urea gel electrophoresis was performed as described elsewhere (Maniatis et al., 1982). DNA samples were mixed with $5 \times$ toading buffer containing $10 \%(w / v)$ Ficoll, $0.1 \%$ SDS, $0.35 \%$ bromophenol blue, and $5 \times$ TBE, and loaded onto $0.5 \times 19.6 \times 25.3 \mathrm{~cm}$ or $0.5 \times 19.6 \times 15.4 \mathrm{~cm}$ agarose, or $0.1 \times 16 \times 16 \mathrm{~cm}$ acrylamide gels in TBE. Agarose gels $(0.8 \%-2 \%)$ were run at $4^{\circ} \mathrm{C}$ at $-4 \mathrm{~V} / \mathrm{cm}$. Nondenaturing $(6 \%-8 \%)$ acrylamide gels were prepared from 19:1 acrylamide:bisacrylamide solution and run at $4^{\circ} \mathrm{C}$ at $5 \mathrm{~V} / \mathrm{cm}$. Denaturing gel samples were diluted in $90 \%$ formamide containing $1 \mathrm{mM}$ EDTA, $0.05 \%$ bromphenol blue, and $0.05 \%$ xylene cyanol, heated to $95^{\circ} \mathrm{C}$ for $10 \mathrm{~min}$, loaded onto $8 \%$ acrylamide-7 $\mathrm{M}$ urea gel, and electrophoresed at room temperature at $30 \mathrm{~V} / \mathrm{cm}$. Field reversal pulse electrophoresis was done using a programmable power inverter PPI-200 (MJ Research, Inc.) at $8 \mathrm{~V} / \mathrm{cm}$. During electrophoresis the forward and reverse pulses were varied from 0.15 to $4.8 \mathrm{~s}$ and 0.05 to $1.6 \mathrm{~s}$, respectively. The gels were stained with $0.5 \mu \mathrm{g} / \mathrm{ml}$ ethidium bromide and photographed as described else where (Vincenz et al., 1991). DNA was transferred to nylon for $12 \mathrm{hr}$ at $0.5 \mathrm{~A}$, using $0.5 \times$ TBE using a Hoefer Transphor unit. The DNA was fixed and denatured using $\mathrm{NaOH}$ (Vincenz et al., 1991). Prehybridization was done in $1.5 \times$ SSPE, $0.1 \mathrm{mg} / \mathrm{ml}$ Escherichia coli DNA $1 \%$ SDS, and $0.5 \%$ Carnation nonfat milk at $50^{\circ} \mathrm{C}$ overnight, using a Hoefer hybridization oven. Hybridizations were done at the same conditions for $16 \mathrm{hr}$ using one or more of four probes: TEL4, kinaselabeled synthetic oligonucleotide (TTAGGG); RAT, random primerlabeled bulk rat DNA; and M, random primer-labeled 123 bp marker DNA or Mspl-digested pBR322 DNA. Membranes were washed at $25^{\circ} \mathrm{C}$ for $10 \mathrm{~min}$ with $2 \times \mathrm{SSC}, 1 \times \mathrm{SSC}, 0.5 \times \mathrm{SSC}, 0.1 \times \mathrm{SSC}$, and then for $30 \mathrm{~min}$ at $50^{\circ} \mathrm{C}$ with $0.1 \times$ SSC, $0.1 \%$ SDS. If the last washing step was at $55^{\circ} \mathrm{C}$, the telomere hybridization decreased more than 10-fold, indicating a high stringency at $50^{\circ} \mathrm{C}$. If salmon sperm DNA was substituted for $E$. coli, the telomere hybridization significantly decreased, as expected. These precautions are important for eliminating nonstringent hybridization to nontelomere sequences that are found near the centromeres of certain cells such as CHO (D'Anna and Tobey, 1989). Dot blot analyses were performed as described by Vincenz et al. (1991), using the same prehybridization and hybridization conditions. After hybridization, the telomere probe was stripped wice with $0.1 \times$ SSC, $0.5 \%$ SDS at $95^{\circ} \mathrm{C}$ for $15 \mathrm{~min}$, and the membrane was hybridized with random primer-labeled bulk rat DNA. Membranes were exposed to preflashed X-OMAT film (Kodak) for $6-60 \mathrm{hr}$ at $-70^{\circ} \mathrm{C}$. Autoradiograms and images of ethidium bromide-stained gels were digitized using a cooled CCD camera (Vincenz et al., 1991). The data were analyzed by using IGOR (Wave Metrics).

\section{Nucleoprotein Gel Electrophoresis}

Solubilized chromatin was digested at $37^{\circ} \mathrm{C}$ for different times with

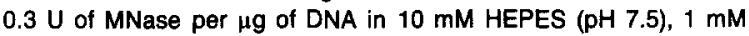
$\mathrm{CaCl}_{2}$ mixed with an equal volume of glycerol and loaded onto a $6 \%$ acrylamide gel, prepared as described (Varshavsky et al., 1976) except using $10 \mathrm{mM}$ Tris-acetate ( $\mathrm{pH}$ 8.5). The gel was preelectrophoresed for $3 \mathrm{hr}$ at $50 \mathrm{~V}$ and $2 \mathrm{~mA}, 5 \mu \mathrm{g}$ of nucleoprotein was loaded, and the gel was electrophoresed at $150 \mathrm{~V}$ and $9 \mathrm{~mA}$ for $2 \mathrm{hr}$ with intensively recirculating buffer ( $10 \mathrm{ml} / \mathrm{min})$. The gel was stained with ethidium bromide, photographed, and incubated for $1 \mathrm{hr}$ at $37^{\circ} \mathrm{C}$ with $500 \mathrm{ml}$ of $1 \%$ Sarkosyl solution containing $10 \mathrm{mg}$ of proteinase $\mathrm{K}$, and then the DNA was transferred to the nylon membrane.

Preparation of H1-Depleted Chromatin and Protein Analysis $\mathrm{H} 1$ depletion for sedimentation analyses was by the method of Marekov and Beltchev $(1981)$. Hat nuclei $(350 \mu \mathrm{g})$ in $200 \mu$ l of buffer $C$ were incubated with $1 \mathrm{mM} \mathrm{CaCl}_{2}$ for $5 \mathrm{~min}$ at $37^{\circ} \mathrm{C}$ and digested with 80 $U$ of MNase for $3.5 \mathrm{~min}$. The reaction was stopped with $10 \mathrm{mM}$ EDTA, the nuclei were sedimented gently and lysed for $1 \mathrm{hr}$ on ice in $280 \mu$ Bio-Rex 70 buffer (1 mM EDTA, $8 \mathrm{mM} \mathrm{Na}_{2} \mathrm{HPO}_{4}$ [pH 7.0], and $0.1 \mathrm{mM}$ PMSF), and the soluble chromatin was collected from the supernatant after microcentrifugation for $5 \mathrm{~min}$. To remove $\mathrm{H} 1$ selectively, the chromatin was mixed with an equal volume of Bio-Rex 70 (Bio-Rad, 200400 mesh), equilibrated with Bio-Rex 70 buffer, gently shaken for 2 $\mathrm{hr}$, and then sedimented at $300 \times \mathrm{g}$ for $5 \mathrm{~min}$.

$\mathrm{H} 1$ depletion for MNase studies of the nucleosome core particles was performed by conventional treatment with $0.5 \mathrm{M} \mathrm{NaCl}$ (Butler and Thomas, 1980). Chromatin in Bio-Rex 70 buffer $(500 \mu \mathrm{g} / \mathrm{ml}, 0.5 \mathrm{ml})$ was mixed with an equal volume of $1 \mathrm{M} \mathrm{NaCl}$, placed into a Centricon 100 centrifugal microconcentrator (Amicon), and spun at $1000 \times \mathrm{g}$ for $\mathbf{2 5} \mathrm{min}$. To remove salt, centrifugation was repeated after addition of $1 \mathrm{ml}$ of TE buffer.

Electrophoresis in $15 \%$ polyacrylamide-SDS gels confirmed lack of protein degradation of nuclei, soluble chromatin, $\mathrm{H} 1$-depleted chromatin, and oligonucleosomes after sucrose gradient centrifugation and also confirmed complete removal of $\mathrm{H} 1$ after both depletion procedures. Quantitation of Coomassie staining was done using the CCD camera.

\section{Analysis of Sedimentation Coefficients}

Soluble chromatin $(30-35 \mu \mathrm{g})$ in $250 \mu \mathrm{l}$ was loaded onto cold $5 \%$ $31 \%$ isokinetic exponential sucrose gradients $(9.3 \mathrm{ml}$ mixing volume) containing $10 \mathrm{mM}$ HEPES (pH 7.5), $1 \mathrm{mM}$ EDTA, and $0.2 \mathrm{mM}$ PMSF. Centrifugation was done at $4^{\circ} \mathrm{C}$ with an SW-40 rotor in a Beckman L5-65 at $29,000 \mathrm{rpm}$ for $12 \mathrm{hr}$. Fractions of $100 \mu \mathrm{l}$ were collected, incubated overnight at $37^{\circ} \mathrm{C}$ in $0.5 \%$ SDS, $0.5 \mathrm{mg} / \mathrm{ml}$ proteinase $\mathrm{K}$, and then mixed with loading buffer. Electrophoresis, staining, electrotransfer, hybridization, and quantltation were carrled out as above. Integrated fluorescence and densities of oligonucleosomes with the same molecular weights were analyzed using IGOR. The centers of the sedimentation profiles of bulk or telomere DNA were determined by Gaussian fit and agreed with centers chosen by eye from the fluorograms and autoradiograms. The profiles of fluorescence agreed quantitatively with the $A_{280}$ recorded during fraction collection. The gradients were confirmed to be isokinetic and exponential by centrifugation of tobacco mosaic virus for different times and measurement of refractive index.

\section{Acknowledgments}

This work was supported by National Institutes of Health (NIH) grant GM44403 and National Science Foundation grant DMB9106659; J. B. was supported by NIH training grant 5T32GM07315.

Received November 4, 1992; revised March 9, 1993.

\section{References}

Allshire, R. C., Gosden, J. R., Cross, S. H., Cranston, G., Rout, D. Sugawara, N., Szostak, J. W., Fantes, P. A., and Hastie, N. D. (1988). Telomeric repeat from $T$. thermophila cross hybridizes with human telomeres. Nature 332, 656-659.

Barsoum, J., and Varshavsky, A. (1985). Preferential localization of variant nucleosomes near the 5'-end of the mouse dihydrofolate reductase gene. J. Biol. Chem. 260, 7688-7697.

Bavykin, S. G., Usachenko, S. I., Zalensky, A. O., and Mirzabekov, A. D. (1990). Structure of nucleosomes and organization of internucleosomal DNA in chromatin. J. Mol. Biol. 212, 495-511.

Berman, J., Tachibana, C. Y., and Tye, B.-K. (1986). Identification of a telomere-binding activity from yeast. Proc. Natl. Acad. Sci. USA 83 , 3713-3717.

Blackburn, E. H. (1984). Telomeres: do the ends justify the means? Cell 37, 7-8.

Blackburn, E. H. (1991a). Structure and function of telomeres. Nature $350,569-573$

Blackburn, E. H. (1991b). Telomeres. Trends Biochem. Sci. 16, 378381 
Blackburn, E. H. (1992). Telomerases. Annu. Rev. Biochem. 61, 113129.

Blackburn, E. H., and Chiou, S.S. (1981). Non-nucleosomal packaging of a tandemly repeated DNA sequence at termini of extrachromosomal DNA coding for rRNA in Tetrahymena. Proc. Natl. Acad. Sci. USA 78 , 2263-2267.

Blackburn, E. H., and Gall, J. G. (1978). A tandemly repeated sequence at the termini of the extrachromosomal rRNA genes in Tetrahymena. J. Mol. Biol. 120, 33-53.

Blackburn, E. H., and Szostak, J. W. (1984). The molecular structure of centromeres and telomeres. Annu. Rev. Biochem. 53, 163-194.

Buchman, A. R., Kimmerly, W. J., Rine, J., and Kornberg, R. D. (1988) Two DNA-binding factors recognize specific sequences at silencers, upstream activating sequences, autonomously replicating sequences, and telomeres in Saccharomyces cerevisiae. Mol. Cell. Biol. 8, 210225.

Budarf, M. L., and Blackburn, E. H. (1986). Chromatin structure of the telomeric region and 3 '-nontranscribed spacer of Tetrahymena ribosomal RNA genes. J. Biol. Chem. 261, 363-369.

Burton, D. R., Butler, J. J., Hyde, J. E, Phillips, D., Scidmore, C. J., and Walker, I. O. (1978). The interaction of core histones with DNA: equilibrium binding studies. Nucl. Acids Res. 5, 3643-3663.

Butler, P. J. G., and Thomas, J. O. (1980). Changes in chromatin folding in solution. J. Mol. Biol. 140, 505-529.

Chung, H. M., Shea, C., Fields, S., Taub, R. N., Van der Ploeg, L. H., and Tse, D. B. (1990). Architectural organization in the interphase nucleus of the protozoan Trypanosoma brucei: location of telomeres and mini-chromosomes. EMBO J. 9, 2611-2619.

Conrad, M. N., Wright, J. H., Wolf, A. J., and Zakian, V. A. (1990). RAP1 protein interacts with yeast telomeres in vivo: overproduction alters telomere structure and decreases chromosome stability. Cell $63,739-750$.

Coren, J. S., Epstein E. M., and Vogt, V. M. (1991). Characterization of a telomere-binding protein from Physarum polycephalum. Mol. Cel. Biol. 11, 2282-2290.

D'Anna, J. A., and Tobey, R. A. (1989). Changes in nucleosome repeat lengths precede replication in the early replicating metallothionein I gene region of cells synchronized in early S phase. Biochemistry 28 , 2895-2902.

de Lange, T. (1992). Human telomeres are attached to the nuclear matrix. EMBO J. 11, 717-724.

Drew, H. R. (1984). Structural specificities of five commonly used DNA nucleases. J. Mol. Biol. 176, 535-557.

Edwards, C. A., and Firtel, R. A. (1984). Site-specific phasing in the chromatin of the rDNA in Dictyostelium discoideum. J. Mol. Biol. 180, 73-90.

Finch, J. T., Noll, M., and Kornberg, R. D. (1975). Electron microscopy of defined lengths of chromatin. Proc. Natl. Acad. Sci. USA 72, 33203322

Foe, V. E., and Alberts, B. (1985). Reversible chromosome condensation induced in Drosophila embryos by anoxia: visualization of interphase nuclear organization. J. Cell Biol. 100, 1623-1636.

Godde, J. S., and Widom, J. (1992). Chromatin structure of Schizosaccharomyces pombe: a nucleosome repeat length that is shorter than the chromatosomal DNA length. J. Mol. Biol. 226, 1009-1025.

Gottschling, D. E., and Cech, T. R. (1984). Chromatin structure of the molecular ends of Oxytricha macronuclear DNA: phased nucleosomes and a telomeric complex. Cell 38, 501-510.

Gottschling, D. E., and Zakian, V. A. (1986). Telomere proteins: specific recognition and protection of the natural termini of Oxytricha macronuclear DNA. Cell 47, 195-205.

Gottschling, D. E., Aparicio, O. M., Billington, B. L., and Zakian, V. A. (1990). Position effect at $S$. cerevisiae telomeres: reversible repression of Pol II transcription. Cell 63, 751-762.

Gruenbaum, Y., Hochstrasser, M., Mathog, D., Saumweber, H., Agard, D. A., and Sedat, J. W. (1984). Spatial organization of the Drosophila nucleus: a three-dimensional cytogenetic study. J. Cell Sci. (Suppl.) 1, 223-234
Harley, C. B., Futcher, A. B., and Greider, C. W. (1990). Telomeres shorten during aging of human fibroblasts. Nature 345, 458-460.

Huang, S.-Y., and Garrard, W. T. (1989). Electrophoretic analyses of nucleosomes and other protein-DNA complexes. Meth. Enzymol. 170, 116-142.

Kipling, D., and Cooke, H. J. (1990). Hypervariable ultra-long telomeres in mice. Nature 347, 400-402

Klobutcher, L. A., Swanton, M. T., Donini, P., and Prescott, D. M. (1981). All gene-sized DNA molecules in four species of hypotrichs have the same terminal sequence and an unusual $3^{r}$ terminus. Proc. Natl. Acad. Sci. USA 78, 3015-3019.

Kornberg, R. D., LaPointe, J. W., and Lorch, Y. (1989). Preparation of nucleosomes and chromatin. Meth. Enzymol. 170, 3-14.

Levinger, L., and Varshavsky, A. (1982). Selective arrangement of ubiquitinated and D1 protein-containing nucleosomes within the Drosophila genome. Cell 28, 375-385.

Liu, A., and Tye, B.-K. (1991). A yeast protein that binds to vertebrate telomeres and conserved yeast telomeric junctions. Genes Dev. 5 4959.

Liu, L. F., and Wang, J. C. (1978). DNA-DNA gyrase complex: the wrapping of the DNA duplex outside the enzyme. Cell 15, 979-984.

Lohr, D., and van Holde, K. E. (1979). Organization of spacer DNA in chromatin. Proc. Natl. Acad. Sci. USA 76, 6326-6330.

Maniatis, T., Fritsch, E. F., and Sambrook, J. (1982). Molecular Cloning: A Laboratory Manual (Cold Spring Harbor, New York: Cold Spring Harbor Laboratory).

Marekov, L. N., and Beltchev, B. (1981). Selective removal of histone H1 from chromatin at low salt concentration. Anal. Biochem. 115, 9396.

McKay, S. J., and Cooke, H. (1992). A protein which specifically binds to single stranded TTAGGG repeats. Nucl. Acids Res. 20,1387-1391.

Meyne, J., Baker, R. J., Hobart, H. H., Hsu, T. C., Ryder, O. A., Ward, O. G., Willey, J. E., Wurster-Hill, D. H., Yates, T. L., and Moyzis, R. K. (1990). Distribution of non-telomeric sites of the (TTAGGG) $n$ telomeric sequence in vertebrate chromosomes. Chromosoma 98, 351-357.

Moyzis, R. K., Buckingham, J. M., Cram. L. S., Dani. M., Deaven, L. L., Jones, M. D., Meyne, J., Ratliff, R. L., and Wu, J.-R. (1988). A highly conserved repetitive DNA sequence, (TTAGGG) ${ }_{n}$, present at the telomeres of human chromosomes. Proc. Natl. Acad. Sci. USA $85,6622-6626$

Noll, H., and Noll, M. (1989). Sucrose gradient techniques and applications to nucleosome structure. Meth. Enzymol. 170, 55-116.

Noll, M. (1974a). Subunit structure of chromatin. Nature 251, 249251.

Noll, M. (1974b). Internal structure of the chromatin subunit. Nucl. Acids Res. 1, 1573-1578

Noll, M., and Kornberg, R. D. (1977). Action of micrococcal nuclease on chromatin and the location of histone H1. J. Mol. Biol. 109, 393404.

Omori, A., Igo-Kemenes, T., and Zachau, H. G. (1980). Different repeat lengths in rat satellite I DNA containing chromatin and bulk chromatin. Nucl. Acids Res. 8, 5363-5375.

Osipova, T. N., Pospelov, V. A., Svetlikova, S. B., and Vorob'ev, V. I. (1980). The role of histone $\mathrm{H} 1$ in compaction of nucleosomes: sedimentation behavior of oligonucleosomes in solution. Eur. J. Biochem. 113, 183-188.

Osipova, T. N., Karpova, E. V., Svetlikova, S. B., Kukushkin, A. N., and Pospelov, V. A. (1986). The structure of chromatin from the pigeon brain. II. Sedimentation analysis of oligonucleosome density. Mol. Biol. (Mosk.) 20, 78-85

Pennings, S., Meersseman, G., and Bradbury, E. M. (1992). Effect of glycerol on the separation of nucleosomes and bent DNA in low ionic strength polyacrylamide gel electrophoresis. Nucl. Acids Res. 20. 6667-6672

Price, C. M. (1990). Telomere structure in Euplotes crassus: characterization of DNA-protein interactions and isolation of a telomere-binding protein. Mol. Cell. Biol. 10, 3421-3431. 
Price, C. M., and Cech, T. R. (1987). Telomeric DNA-protein interactions of Oxitricha macronuclear DNA. Genes Dev. 1, 783-793.

Prunell, A., Kornberg, R. D., Lutter, L., Klug, A., Levitt, M., and Crick, F. H. C. (1979). Periodicity of deoxyribonuclease I digestion of chromatin. Science 204, 855-858.

Rawlins, D. J., Highett, M. I., and Shaw, P. J. (1991). Localization of telomeres in plant interphase nuclei by in situ hybridization and $3 D$ confocal microscopy. Chromosoma 100, 424-431.

Rhodes, D., and Klug, A. (1980). Helical periodicity of DNA determined by enzyme digestion. Nature 286, 573-578.

Richmond, T. J., Finch, J. T., Rushton, B., Rhodes, D., and Klug, A (1984). Structure of the nucleosome core particle at $7 \AA$ resolution. Nature 311, 532-537.

Shampay, J., Szostak, J. W., and Blackburn, E. H. (1984). DNA sequences of telomeres maintained in yeast. Nature 310, 154-157.

Simpson, R. T. (1978). Structure of the chromatosome, a chromatin particle containing 160 base pairs of DNA and all the histones. Bio chemistry 17, 5524-5531.

Spadafora, C., Oudet, P., and Chambon, P. (1979). Rearrangement of chromatin structure induced by increasing ionic strength and temperature. Eur. J. Biochem. 100, 225-235.

Starling, J. A., Maule, J., Hastie, N. D., and Allshire, R. C. (1990). Extensive telomere repeat arrays in mouse are hypervariable. Nucl. Acids Res. 18, 6881-6888.

van Dekken, H., Pinkel, D., Mullikin, J., Trask, B., van den Engh, G., and Gray, J. (1989). Three-dimensional analysis of the organization of human chromosome domains in human-hamster hybrid interphase nuclei. J. Cell. Sci. 94, 299-306.

van Holde, K. E. (1989). Chromatin (New York: Springer-Verlag)

Varshavsky, A. J., Bakayev, V. V., and Georgiev, G. P. (1976). Heterogeneity of chromatin subunits in vitro and location of histone $\mathrm{H} 1$. Nucl. Acids Res. 3, 477-492.

Villeponteau, B., Brawley, J., and Martinson, H. G. (1992). Nucleosome spacing is compressed in active chromatin domains of chick erythroid cells. Biochemistry 31, 1554-1563.

Vincenz, C., Fronk, J., Tank, G. A., and Langmore, J. P. (1991). Nucleoprotein hybridization: a method for isolating active and inactive genes as chromatin. Nucl. Acids Res. 19, 1325-1336.

Watkins, J. F., and Smerdon, M. J. (1985). Nucleosome rearrangement In vitro. 1. Two phases of salt-induced nucleosome migration in nuclei. Biochemistry 24, 7279-7287.

Wright, J. F., and Shay, J. W. (1992). Telomere positional effects and the regulation of cellular senescence. Trends Genet. 8, 193-197.

Wright, J. H., Gottschling, D. E., and Zakian, V. A. (1992). Saccharomyces telomeres assume a non-nucleosomal chromatin structure. Genes Dev. 6, 197-210.

Zakian, V. A. (1989). Structure and function of telomeres. Annu. Rev. Genet. 23, 579-604.

Zhong, Z., Shive, L., Kaplan, S., and de Lange, T. (1992). A mammalian factor that binds telomeric TTAGGG repeats in vitro. Mol. Cell. Biol. 12. 4834-4843. 